\title{
Perceptions of Executives in Implementation of IFRS in India- A Factor Analysis
}

\author{
Satyanarayana Gardasu ${ }^{1}$ Prof. D. Suryachandra Rao ${ }^{2}$ \\ ${ }^{1}$ Research Scholar (Ph.D.) Krishna University Machilipatnam, A.P. \\ ${ }^{2}$ Dean, Faculty of Commerce \&Mgt Krishna University Machilipatnam, A.P.
}

\begin{abstract}
The main purpose of the empirical research of the study is to evaluate the factors affecting the IFRS Implementation in India with the help of descriptive statistics and Factor analysis.This study based on primary data.The primary information collected from 40 respondent's through questionnaire from executives of Indian companies. The questionnaire covered the questions on various issues, challenges, and suggestions pertaining to implementation/adoption of IFRS. The Empirical findings of the study are there is anImpact of IFRS Implementation on the financial performance of Indian Companies by Using Descriptive Statistics, and the Factor analysis reveals that six factors whose cumulative \% of Variance is 72.347 out of which from screen plot we see four are most important. One can conclude that the four factors (1,2, 3 and 4) are influencing up to $59.733 \%$ in which questions $15,16,17,18,19,23,22,24,25,26,27,10,12,28,13$ and 14 are present which should not be neglected because of that we are excluding three questions 11,20 and 21. For population also it is likely to be same. Finally, it is recommended to Government, Companies, and ICAI,develop new steps for better improvement in Indian Financial Reporting System for accounting users throughout the world.
\end{abstract}

Keywords: IFRS, Executives Perceptions, Factor Analysis

\section{Introduction}

The growing international shareholding and trade forced organizations and Chartered Accountants to design a common global accounting language. As a consequence, the International Financial Reporting Standards (IFRS) was designed as a common global accounting language for business affairs so that company accounts are understandable and comparable across international boundaries. The IFRS is particularly important for companies that have dealings in several countries to reflect the true and fair view of the business affairs. Many countries use or are moving towards using the IFRS, which were established and maintained by the International Accounting Standards Board (IASB). The IFRS began as an attempt to harmonize accounting across the European Union and spread quickly the entire world.

\section{The Need For And Importance Of The Study}

The Institute of Chartered Accountants of India (ICAI) has announced that IFRS will be mandatory in India for financial statements for the periods beginning on or after $1^{\text {st }}$ April 2016 in a phased manner. The ICAI has also stated that IFRS will be applied to companies above INR 1000 crore (INR 10 billion) from April 2011. Phase wise applicability details for different companies in India are as follows.

(i) In the first phase- companies included in Nifty Index 50 or BSE Index 30, and companies whose securities are listed on stock exchanges outside India and all other companies having a net worth of INR 1000 crore (10 billion) would prepare and present financial statements using Indian Accounting Standards converging with IFRS.

(ii) In the second phase - Companies, whether listed or not, having a net worth of more than INR 5 billion would convert their opening balance sheet as at $1^{\text {st }}$ April 2013.

(iii) In the third phase - Listed companies having a net worth of INR 5 billion or less would convert their opening balance sheet as at $1^{\text {st }}$ April 2014. Un-listed companies having a net worth of INR 5 billion or less would continueto apply existing accounting standards, which might be modified from time to time.

The size of companies is measured in terms of net worth. In view of the above directions by the Ministry of Corporate Affairs (MCA) and the Institute of Chartered Accountants of India (ICAI), the study on IFRS is important to find out the impact of IFRS implementation or adoption on preparation of financial statements by Indian companies especially the companies which are operating in two or more countries and hence taken up. Based on the importance the adoption of IFRS, the following objectives were framed for the study. (www.mca.org.in) 


\section{Review Of Literature}

Liu et al. (2011) observed that many respondents (80\%) believed IFRS would facilitate consistent regulation, bring greater disclosure in the presentation of information regarding financial reporting and sustainability and corporate governance report would also be more transparent.

GlynisMilne., Dr. Eloisa Perez de Toledo. (2013) wrote an article on "A Stakeholder's Perspective on the Implications of IFRS and Fair Value Accounting on Valuation of Securities". They found that accuracy of a firm's valuation, increase confidence in the reliability and consequently improve the stakeholder's share price and market value. They become more versed in the requirements of fair valuation, the method will become easier to implement.

\section{Objectives Of The Study}

The main objective of the study is to evaluate the factors determine the implementation of IFRS on Financial Statements of Indian companies.

However, in order to give direction to the study, the following specific objectives are set forth. The specific objectives of the study are:

1. To assess the impact of IFRS implementation on Financial Performance of select companies; and

2. To analyze the issues and challenges of IFRS implementation in India.

\section{Methodology}

The study is based on primary and secondary data.The primary information collected through questionnaire from executives of Indian companies. The questionnaire covered the questions on various issues, challenges, and suggestions pertaining to implementation/adoption of IFRS. The term executives include those respondents having knowledge about International Financial Reporting Standards and the existing Indian Accounting Standards. For the purpose or research the target population of was executives divided into two categories: Auditors Accounting professionals working in companies (executives) The questionnaire also contains questions to find out the area of impact on profitability, Net worth, working capital,financial risk, and Investment risk, Depreciation and other functional areas. Another source of primary data is an interview with chartered accountants who gave their valuable comments and suggestion towards successful implementation of IFRS in India. These suggestions or comments were included in an appropriate context. Data collected using questionnaire were analysed through percentages, descriptive statistics, and Factor Analysis by using Statistical Package for Social Sciences (SPSS).

\section{TABLE- 5.1}

\section{Profile of Respondents}

\begin{tabular}{|c|c|c|c|}
\hline & Variable & Frequency & Percentage \\
\hline \multirow[t]{4}{*}{ Gender } & male & 34 & 85 \\
\hline & female & 6 & 15 \\
\hline & Total & 40 & 100 \\
\hline & B. Com, C.A. & 18 & 45 \\
\hline \multirow[t]{5}{*}{ Qualifications } & B.Com, C.A, C.S & 21 & 52.5 \\
\hline & B.Com, C.A, M.Com, & 10 & 25 \\
\hline & B.Com, C.A, M.Com, M.B.A, Ph.D & 1 & 2.5 \\
\hline & Total & 40 & 100 \\
\hline & $0-5$ Years & 10 & 25 \\
\hline \multirow[t]{4}{*}{ Experience } & 6-15 Years & 13 & 32.5 \\
\hline & 16- 25 Years & 13 & 32.5 \\
\hline & 26 Above & 4 & 10 \\
\hline & Total & 40 & 100 \\
\hline \multirow[t]{4}{*}{ Designation } & (a)Auditor of Financial Statement & 4 & 10 \\
\hline & (b)Preparation of Financial Statement & 9 & 22.5 \\
\hline & (c) Both (a \&b) & 27 & 67.5 \\
\hline & Total & 40 & 100 \\
\hline
\end{tabular}


Descriptive Statistics Analysis (PART-A)

Table5.2: Descriptive Statistics of impact of International Financial Reporting Standards (IFRS) Implementation on financial performance in Indian companies ( $\mathrm{N}=40)$. (Questions from 10 to 28)

Table-5.2

\begin{tabular}{|c|c|c|c|c|c|c|c|c|c|c|}
\hline Q.NO. & Factors & $\begin{array}{c}\text { (SA) } \\
(5)\end{array}$ & $\begin{array}{l}\text { (A) } \\
\text { (4) }\end{array}$ & $\begin{array}{c}\text { (DA) } \\
(3)\end{array}$ & $\begin{array}{c}\text { (SDA) } \\
\text { (2) }\end{array}$ & $\begin{array}{c}\text { (UD) } \\
\text { (1) }\end{array}$ & Total & Mean & SD & $\mathrm{CV}$ \\
\hline 10 & $\begin{array}{l}\text { The adoption of IFRS helps } \\
\text { improving transparency, } \\
\text { comparability and usefulness } \\
\text { of accounts to users }\end{array}$ & 34 & 6 & $\mathbf{0}$ & $\mathbf{0}$ & $\mathbf{0}$ & 40 & 4.78 & 0.42 & 0.09 \\
\hline 11 & $\begin{array}{l}\text { The adoption of IFRS } \\
\text { improves the efficiency of } \\
\text { capital market operations }\end{array}$ & 29 & 11 & $\mathbf{0}$ & $\mathbf{0}$ & $\mathbf{0}$ & 40 & 4.75 & 0.44 & 0.09 \\
\hline 12 & $\begin{array}{l}\text { IFRS is better than IAS and } \\
\text { IndAS }\end{array}$ & 0 & 5 & 25 & 6 & 4 & 40 & 2.23 & 1.03 & 0.46 \\
\hline 13 & $\begin{array}{l}\text { The cost of implementation of } \\
\text { IFRS is high as it requires } \\
\text { additional/trained human } \\
\text { resources }\end{array}$ & 3 & 4 & 27 & 6 & $\mathbf{0}$ & 40 & 2.38 & 1.08 & 0.45 \\
\hline 14 & $\begin{array}{l}\text { Implementation of IFRS } \\
\text { is a complex task of financial } \\
\text { reporting }\end{array}$ & $\mathbf{0}$ & 8 & 27 & 3 & 2 & 40 & 2.28 & 0.96 & 0.42 \\
\hline 15 & $\begin{array}{l}\text { IFRS provides full } \\
\text { information and would impact } \\
\text { on key performance } \\
\text { indicators }\end{array}$ & 31 & 7 & 2 & $\mathbf{0}$ & $\mathbf{0}$ & 40 & 4.73 & 0.60 & 0.13 \\
\hline 16 & $\begin{array}{l}\text { Implementation of IFRS } \\
\text { achieves the objectives of } \\
\text { Financial Reporting }\end{array}$ & 37 & 3 & $\mathbf{0}$ & $\mathbf{0}$ & $\mathbf{0}$ & 40 & 4.85 & 0.36 & 0.07 \\
\hline
\end{tabular}

\begin{tabular}{|c|c|c|c|c|c|c|c|c|c|c|}
\hline 17 & $\begin{array}{l}\text { Implementation of IFRS } \\
\text { improves the efficiency of } \\
\text { financial reporting }\end{array}$ & 36 & 4 & 0 & 0 & 0 & 40 & 4.83 & 0.38 & 0.08 \\
\hline 18 & $\begin{array}{l}\text { Implementation of IFRS } \\
\text { makes external financing } \\
\text { easier. }\end{array}$ & 31 & 9 & 0 & 0 & 0 & 40 & 4.78 & 0.42 & 0.09 \\
\hline 19 & $\begin{array}{l}\text { Implementation of IFRS } \\
\text { brings about volatility in } \\
\text { financial reporting }\end{array}$ & 0 & 5 & 26 & 9 & 0 & 40 & 2.00 & 0.88 & 0.44 \\
\hline 20 & $\begin{array}{l}\text { The existing standards (not } \\
\text { IFRS) bring about volatility } \\
\text { /changes in financial } \\
\text { reporting }\end{array}$ & 0 & 2 & 29 & 9 & 0 & 40 & 1.95 & 0.68 & 0.35 \\
\hline 21 & $\begin{array}{l}\text { The existing standards } \\
\text { (IFRS) are of Tax driven in } \\
\text { nature }\end{array}$ & 0 & 0 & 29 & 8 & 3 & 40 & 1.80 & 0.46 & 0.26 \\
\hline 22 & $\begin{array}{l}\text { The IFRS are of Tax driven } \\
\text { in nature }\end{array}$ & 0 & 1 & 26 & 12 & 1 & 40 & 1.78 & 0.62 & 0.35 \\
\hline 23 & $\begin{array}{l}\text { Implementation of IFRS } \\
\text { would be cumbersome }\end{array}$ & 0 & 2 & 9 & 28 & 1 & 40 & 1.55 & 0.88 & 0.56 \\
\hline 24 & $\begin{array}{l}\text { Fair Value Accounting } \\
\text { (FVA) is more informative } \\
\text { than Historical Cost } \\
\text { Accounting (HCA) }\end{array}$ & 24 & 13 & 2 & 1 & 0 & 40 & 4.63 & 0.63 & 0.14 \\
\hline 25 & $\begin{array}{l}\text { Financial Statements based } \\
\text { on FVA are more transparent } \\
\text { than those prepared using } \\
\text { HCA }\end{array}$ & 31 & 8 & 1 & 0 & 0 & 40 & 4.73 & 0.72 & 0.15 \\
\hline 26 & $\begin{array}{l}\text { FVA will enhance } \\
\text { transparency for } \\
\text { comparability }\end{array}$ & 30 & 8 & 2 & 0 & 0 & 40 & 4.68 & 0.83 & 0.18 \\
\hline 27 & $\begin{array}{l}\text { FVA limits the company's } \\
\text { ability to manipulation their } \\
\text { net income }\end{array}$ & 8 & 27 & 0 & 5 & 0 & 40 & 3.93 & 1.07 & 0.27 \\
\hline 28 & $\begin{array}{l}\text { FVA method is a complex } \\
\text { method for financial } \\
\text { reporting }\end{array}$ & 2 & 4 & 24 & 9 & 1 & 40 & 2.40 & 1.28 & 0.53 \\
\hline
\end{tabular}




\section{INTERPRETATION}

Nineteen questions were distributed to assess the benefits of IFRS implementation in Indian. The mean response of the nineteen questions under benefits of implementation of IFRS and its impact on India companies were more than 1.55 and the standard deviation was also less than 0.36 , which indicates that the respondents perception were close to one another. Finally, it is revealed that on average the respondents agreed with the proposition that implementation of IFRS has many benefits in India. And also reveals that there is an impact of IFRS Implementation on financial performance of Indian Companies.

\section{FACTOR ANALYSIS PART - B}

Factor analysis is a statistical method used to recount variability among observed, correlated variables in terms of a possibly lower number of unobserved variables called factors. The multiple observed variables are the main key concept of factor analysis because it has similar patterns of responses because they are all associated with a latent (i.e. not directly measured) variable. It allows researchers to investigate concepts that are not easily measured directly by reducing a large number of variables into a few interpretable underlying factors.40 questionnaire forms received by way of primary data collection were loaded into the SPSS software for the Initial analysis. Overall, there were 19 variables (Questionnaire), which were having an impact of IFRS implementation on the financial performance of the selected companies. However, to come out with a Discriminant Analysis output with all the 19 (Questionnaire), would lead to a very lengthy model. Tocounterthesame,theFactorAnalysiswasusedforthedatareduction.

\section{FactorAnalysisResults}

The study identified various factors influencing the financial performance of selected companies. These factors will determine theImplementation of IFRS key performance indicator, Fair Value Accounting, IFRS Financial Reporting,Cost Controllingetc. Factors are as follows:

TheKaiser-Meyer-Olkinistheevaluateofsamplingadequacy, which changes between 0 and 1. The values closer to 1 are better and the value of 0.6 is there commended minimum. The Bartlett's Test of Sphericity is the test for the null hypothesis that the correlation matrix has an identity matrix. Taking this into consideration, these tests provide the minimum standard to proceed for Factor Analysis.

Source: (shodhganga.inflibnet.ac.in)

\begin{tabular}{|c|c|c|}
\hline \multicolumn{3}{|c|}{ KMO and Bartlett's Test } \\
\hline Kaiser-Meyer-O & Sampling Adequacy. & .519 \\
\hline Bartlett'sTestof & Approx. Chi-Square & $\begin{array}{l}337.459 \\
171\end{array}$ \\
\hline Sphericity & $\begin{array}{l}\text { df } \\
\text { Sig. }\end{array}$ & $\begin{array}{l}171 \\
.000\end{array}$ \\
\hline
\end{tabular}

Conclusion: Generally, if Kaiser-Meyer-Olkin Measure of Sampling Adequacy is more than 0.60 we go for Factor Analysis but here it is less than 0.60. Also, it should have a significant value less than 0.05 for Bartlett's Test of Sphericity which is satisfied.Bartlett'sTestofSphericity Takinga95\%levelofSignificance, $\alpha=0.05$. Thepvalue (Sig.) of. $000<0.05$, there fore the Factor Analysis is valid. So if we go for factor analysis following are the results and interpretation. TheKaiser-Meyer Olkin (KMO) and Bartlett's Test measure of sampling adequacy were used to examine the appropriateness of Factor Analysis. The approximate of Chi-square is 337.459 with 171 degrees of freedom, which is significant at 0.05 Level of significance. The KMO statistic of 0.519 is also large (less than 0.50) Bartlett's Test of Sphericity is satisfied. Hence Factor Analysis is considered as an appropriate technique for further analysis of the data.

Table - 5.3

Communalities

\begin{tabular}{|c|c|c|}
\hline Statement & Initial & Extraction \\
\hline $\begin{array}{l}\text { Q10. The adoption of IFRS helps improving transparency, comparability and usefulness of account } \\
\text { to users. }\end{array}$ & 1.000 & .725 \\
\hline Q13. The Cost of implementation of IFRS is high as it requires additional/trained human resources. & 1.000 & .804 \\
\hline Q15. IFRS provides full information and would impact on key performance indicators & 1.000 & 832 \\
\hline Q16. Implementation of IFRS achieves the objectives of Financial Reporting & 1.000 & .776 \\
\hline Q17.Implementation of IFRS improves the efficiency of financial reporting. & 1.000 & .757 \\
\hline
\end{tabular}




\begin{tabular}{|c|c|c|}
\hline Q18. Implementation of IFRS makes external financing easier. & 1.000 & .661 \\
\hline \multirow{2}{*}{$\begin{array}{l}\text { Q19. Implementation of IFRS brings about volatility in in financial reporting. } \\
\text { Q20. The existing standards (not IFRS) bring about volatility/changes in financial reporting. }\end{array}$} & 1.000 & .793 \\
\hline & 1.000 & .825 \\
\hline \multirow{2}{*}{$\begin{array}{l}\text { Q21. The existing standards (not IFRS) are of Tax driven in nature } \\
\text { Q22. The IFRS are of Tax driven in nature. }\end{array}$} & 1.000 & .718 \\
\hline & 1.000 & .330 \\
\hline \multirow{2}{*}{$\begin{array}{l}\text { Q23. Implementation of IFRS would be cumbersome } \\
\text { Q24 Fair Value Accounting (FVA) is more Informative than Historical Cost Accounting (HCA). }\end{array}$} & 1.000 & .728 \\
\hline & 1.000 & .794 \\
\hline \multirow{2}{*}{$\begin{array}{l}\text { Q25. Financial Statements based on FVA are more transparent than those prepared using HCA } \\
\text { Q26. FVA will enhance transparency for comparability. }\end{array}$} & 1.000 & .708 \\
\hline & 1.000 & .738 \\
\hline Q27. FVA limits the company's ability to manipulate their net income. & 1.000 & .666 \\
\hline Q28. FVA method is a complex method for financial reporting. & 1.000 & .724 \\
\hline
\end{tabular}

Extraction Method: Principal Component Analysis.

Conclusion: In the above table if the extraction value is more one can say that most of the respondents are agreeing with that factor.

\section{Table-5.4}

Total Variance Explained

\begin{tabular}{|c|c|c|c|c|c|c|c|}
\hline \multirow{2}{*}{$\begin{array}{l}\text { Compone } \\
\text { nt }\end{array}$} & \multicolumn{3}{|c|}{ Initial Eigenvalues } & \multicolumn{3}{|c|}{ Extraction Sums of Squared Loadings } & \multirow{2}{*}{\begin{tabular}{|l|}
$\begin{array}{l}\text { Rotation Sums } \\
\text { Squared Loadings }\end{array}$ \\
Total
\end{tabular}} \\
\hline & Total & $\%$ of Variance & Cumulative \% & Total & $\%$ of Variance & Cumulative \% & \\
\hline 1 & 3.922 & 20.644 & 20.644 & 3.922 & 20.644 & 20.644 & 3.348 \\
\hline 2 & 3.076 & 16.191 & 36.835 & 3.076 & 16.191 & 36.835 & 2.979 \\
\hline 3 & 2.438 & 12.834 & 49.669 & 2.438 & 12.834 & 49.669 & 2.973 \\
\hline 4 & 1.912 & 10.064 & 59.733 & 1.912 & 10.064 & 59.733 & 1.832 \\
\hline 5 & 1.212 & 6.380 & 66.112 & 1.212 & 6.380 & 66.112 & 1.586 \\
\hline 6 & 1.185 & 6.234 & 72.347 & 1.185 & 6.234 & 72.347 & 1.966 \\
\hline 7 & .958 & 5.044 & 77.390 & & & & \\
\hline 8 & .763 & 4.017 & 81.407 & & & & \\
\hline 9 & .625 & 3.290 & 84.698 & & & & \\
\hline 10 & .541 & 2.847 & 87.544 & & & & \\
\hline 11 & .480 & 2.525 & 90.070 & & & & \\
\hline 12 & .462 & 2.429 & 92.499 & & & & \\
\hline 13 & .390 & 2.055 & 94.554 & & & & \\
\hline 14 & .318 & 1.673 & 96.227 & & & & \\
\hline 15 & .199 & 1.048 & 97.275 & & & & \\
\hline 16 & 169 & .890 & 98.166 & & & & \\
\hline 17 & .160 & .843 & 99.009 & & & & \\
\hline 18 & .116 & 609 & 99.618 & & & & \\
\hline 19 & .073 & 382 & 100.000 & & & & \\
\hline
\end{tabular}

To find out the influencing factors on the financial performance of IFRS implementation of select Indiar companies, factor analysis is used. It should be clear that the first few factors explain the relatively large amount of variance whereas subsequent factors explain only small amounts of variance. SPSS then extract: all factors with Eigen values greater than 1, which are six factors in the above table. First six component: showinfluence 72.34 percent of cumulative variance on the financial performance of select Indian companie: by using IFRS. The above analysis also indicates that higher values have more influence on the financia performance of IFRS implementation of selected companies.

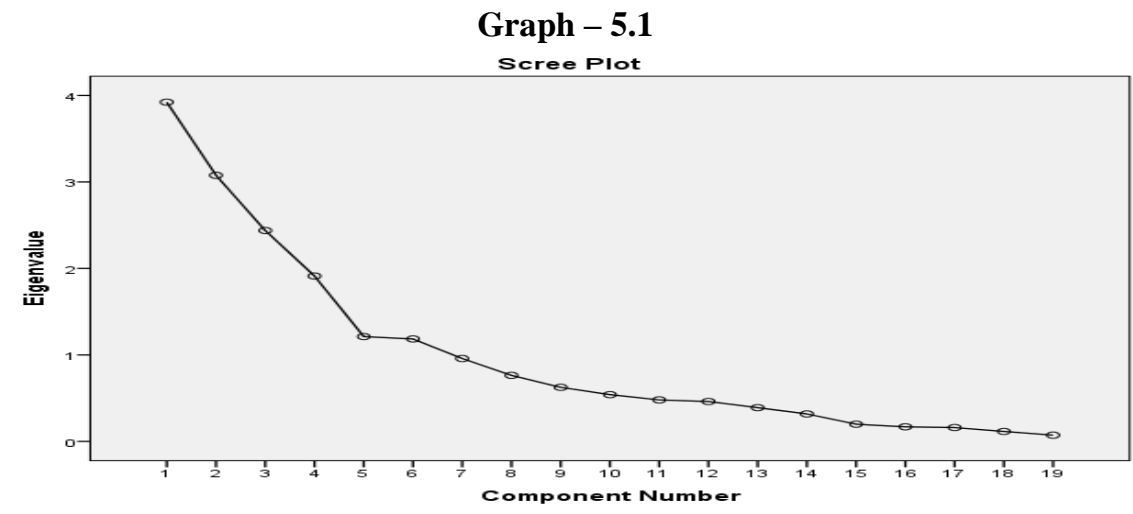


Table -5.5 Component Matrix

\begin{tabular}{|c|c|c|c|c|c|c|}
\hline & & & & pponen & & \\
\hline & 1 & 2 & 3 & 4 & 5 & 6 \\
\hline $\mathrm{Q} 23$ & -.826 & & & & .111 & -.137 \\
\hline Q16 & .789 & .151 & -.269 & & & -.219 \\
\hline Q17 & .684 & .463 & -.184 & & -.180 & \\
\hline Q18 & .536 & & .173 & .254 & .527 & \\
\hline Q15 & .528 & -.311 & .430 & .186 & .241 & .422 \\
\hline Q19 & -.525 & .395 & -.320 & .420 & & -.288 \\
\hline Q26 & & .821 & .151 & -.177 & & \\
\hline Q25 & .182 & .741 & .278 & -.117 & & .170 \\
\hline Q24 & .225 & .727 & .411 & & .177 & \\
\hline Q27 & -.343 & .546 & 395 & -.104 & -.276 & \\
\hline Q22 & -.273 & .499 & & & & \\
\hline Q12 & -.229 & .286 & -.609 & & & -0.107 \\
\hline Q28 & -.493 & & .606 & 316 & & \\
\hline Q10 & .533 & .238 & -.543 & 203 & & -.217 \\
\hline Q14. & & .158 & -.235 & 832 & & .259 \\
\hline Q13 & .106 & & & 708 & -.510 & .151 \\
\hline Q20 & -.586 & & & 361 & .588 & \\
\hline Q11 & .207 & .112 & .579 & & & -.633 \\
\hline Q21 & -.236 & .304 & -.401 & -.293 & 292 & .488 \\
\hline
\end{tabular}

Extraction Method: Principal Component Analysis.

\section{Source: SPSS}

While preparing final factor analysis table each question with the highest value (ignore sign) goes to the related factor. In the above, first row the highest value 0.826 belongs to $1^{\text {st }}$ column i.e., component/ factor ' 1 ' therefore question no 23 goes to factor 1 . In the same manner, all variable identified with factors and summarized as below:

Table -5.6

Questions combined in factors:

\begin{tabular}{|l|l|l|l|}
\hline Factors & Questions & \% of variance & Cumulative \% \\
\hline 1 & $15,16,17,18,19,23$ & 20.644 & 20.644 \\
\hline 2 & $22,24,25,26,27$ & 16.191 & 36.835 \\
\hline 3 & $10,12,28$ & 12.834 & 49.669 \\
\hline 4 & 13,14 & 10.064 & $\mathbf{5 9 . 7 3 3}$ \\
\hline 5 & 20 & 6.380 & 66.112 \\
\hline 6 & 11,21 & 6.234 & 72.347 \\
\hline
\end{tabular}

Interpretation: In the above table, we take the desired or required factors into consideration. As here we have six factors whose cumulative \% of Variance is 72.347 out of which from screen plot we see four are most important. One can conclude that the four factors (1, 2, 3 and 4) are influencing up to $59.733 \%$ in which questions $15,16,17,18,19,23,22,24,25,26,27,10,12,28,13$ and 14 are present which should not be neglected because of that we are excluding three questions 11, 20 and 21. For population also it is likely to be same.

Note:-We can also consider the three questions by taking all six factors; there is no hard and fast rule for that.

Factor 1: Key performance indicators, objectives of Financial Reporting, the efficiency of financial reporting, external financing easier, volatility in financial reporting, and cumbersome.Factor 1 is named as IFRSImplementation key performance indicator.Therefore, Factor 1 should not ignore while understanding of the financial performance of the companies.

Factor 2: Tax-driven in nature, Informative than Historical Cot Accounting (HCA), transparent than those prepared using HCA, transparency for comparability, and ability to manipulate their net income.Factor 2 is named as Fair Value Accounting (FVA).

Factor 3: Improving transparency\& comparability,IFRS is better than IAS and Ind-AS, complex method for financial reporting. Factor 3 is named as IFRS Financial Reporting.

Factor 4: The Cost of implementation of IFRS, complex task of financial reporting.Factor 4 is named as Cost Controlling.

\section{Conclusion}

Based on the descriptive statistics analysis it is concluded that there is an impact of IFRS Implementation on the financial performance of Indian companies. The Factor analysis reveals that six factors whose cumulative \% of Variance is 72.347 out of which from screen plot we see four are most important. One can conclude that the four factors (1, 2, 3 and 4) are influencing up to $59.733 \%$ in which questions $15,16,17,18$, 
$19,23,22,24,25,26,27,10,12,28,13$ and 14 are present which should not be neglected because of that we are excluding three questions 11,20 and 21 . For population also it is likely to be same.

\section{Suggestions}

On the basis of analysis of primary and secondary data researcher wants to give some suggestions to various parties relating directly and indirectly to convergence process of IFRS. These suggestions are based on the perspective of professional Chartered accountants and Accounting Professionals which researcher has collected from primary data collected through questionnaire and personal interviews.

\section{Suggestions to Government}

A) The Government should set rules regarding Fair Valuation Accounting which is an important challenge in convergence process. The government should clearly mention the rules of fair valuation in easy and simple form so that laymen can also understand the fair valuation rules. Fair valuation can affect the financial reports very highly.

B) Government should make some changes in syllabus of accountancy in various boards and universities for giving knowledge about new regulations of IFRS because the youth is the ultimate group who will become the future accounting professionals.

\section{Suggestions to ICAI}

C) ICAI should make compulsory certificate course for members of ICAI to give knowledge of IFRS.

D) To give knowledge of IFRS to existing accounting professional and chartered accountants ICAI should implement a compulsory short duration certificate course for all existing chartered accountants and accounting professionals.

\section{Suggestions to Companies}

E) Give training to staff or arrange some dedicated staff for the convergence process. So that planning and implementation both will get a start soon and ends with proper care and on time.

\section{References}

[1] Liu, C., Yao, L. J., Hu, N., \& Liu, L. (2011). The Impact of IFRS on Accounting Quality in a Regulated Market an Empirical Study of China. Journal of Accounting, Auditing \& Finance, 26(4), 659-676.

[2] Glynis Milne., Dr. Eloisa Perez de Toledo. (2013) "A Stakeholder's Perspective on the Implications of IFRS and Fair Value Accounting on Valuation of Securities".Earth Common Journal Special Issue, MacEwan University, School of Business Volume 3, Number 2.

[3] www.mca.org.in

[4] SPSS ( Statistical Package for Social Sciences)

[5] http://shodhganga.inflibnet.ac.in/bitstream/10603/9094/10/10_chapter\%208.pdf. 